Research Article / Araşttrma Makalesi

\title{
TECHNOLOGY READINESS AND TECHNOLOGY ACCEPTANCE OF ACADEMIC STAFFS
}

\author{
Prof. Dr. Hülya BAKIRTAŞ (D) \\ Aksaray University, FEAS, Aksaray, Turkey, (hbakirtas@hotmail.com) \\ Res. Asst. Cemil AKKAŞ \\ Aksaray University, FEAS, Aksaray, Turkey, (cemilakkas@gmail.com)
}

\begin{abstract}
Technology Reading Index (TRI) has used to determine individuals' willingness to use of technology. This study focuses on differences among belief and use new technology of academic staffs. The article examines how each dimension (optimism, innovativeness, discomfort, insecurity) of Technology Reading Index (TRI) influences Technology Acceptance Model (TAM) which have consumer perceived usefulness and perceived ease of use dimensions. The results show that of optimism dimension of TRI has a positive effect on both consumers perceived usefulness and perceived ease of use while innovativeness dimension has a positive effect on perceived ease of use. Researches on TRI and TAM have overlooked the potential role of technology readiness and acceptance in the development of academic staff. This study tests belief and use new technology of academic staffs.
\end{abstract}

Keywords: Technology Reading Index, Technology Acceptance Model, New Technology Belief.

\section{AKADEMISYENLERIN TEKNOLOJI HAZIRLIĞI VE TEKNOLOJİ KABULÜ}

\begin{abstract}
ÖZET
Teknoloji Hazırlı İndeksi (TRI), bireylerin teknoloji kullanma istekliliğini belirlemek için kullanılmıştır. Bu çalışma, akademik personelin yeni teknoloji inancı ve kullanımı arasındaki farklılıklara odaklanmaktadır. Bu çalışma Teknoloji hazırlık indeksinin (TRI) her boyutunun (iyimserlik, yenilikçilik, rahatslzlık, güvensizlik), algllan fayda ve kullanım kolaylığı gibi boyutlara sahip olan Teknoloji Kabul Modeli (TAM) ïzerindeki etkisini incelemektedir. Analiz sonuçları, TRI'nin yenilikçilik boyutunun algılanan kullanım kolaylığı üzerinde pozitif etkiye sahip iken, iyimserlik boyutunun ise hem algılanan fayda hem de algılanan kullanım kolaylı̆̆ üzerinde etkiye sahip olduğunu göstermiştir. TRI ve TAM üzerine yapılmuş olan araştırmalar, akademik personelin gelişiminde teknoloji hazırlığı ve kabulünün potansiyel rolünü göz ardı etmiştir. Bu çalışma, akademik personelin yeni teknolojiye karşı inancı ve kullanıminı analiz etmektedir.
\end{abstract}

Anahtar Kelimeler: Teknoloji Hazırlık İndeksi, Teknoloji Kabul Modeli, Yeni Teknoloji İnancı. 


\section{Introduction}

The use of technology increases worldwide 7 billion people (95\% of the global population) have access to a mobile-cellular network (Brahima, 2017: 2). People have affected economically, sociologically and psychologically by technological developments in the world. The effects have been seen positively the process of teaching, learning, research, and searching for information on people (Partala \& Saari, 2015: 381; Kumar, 2012: 144).

New ideas immediately not embrace and adopt both people and firms. This depends on a lot of components (Hagspiel et al., 2015: 897; Parasuraman, 2000: 308). People's beliefs, attitudes and monetary power impact on the diffusion of new ideas. People have positive and negative beliefs that unnecessary, difficult and time consuming about new ideas or new technology. Parasuraman (2000: 308) developed technology readiness index (TRI) to reveal general technology beliefs of an individual. The index has been employed in several studies. One from the subjects of these studies is the relationships between dimensions of TRI and TAM (Godoe \& Johansen, 2012: 38).

In sum, our goal is to determine differences among belief and use new technology of people who have different academic title and each dimension of TRI investigate effect on TAM. The study is structured as follows. Firstly, we present a theoretical background on TRI and TAM. Secondly, we present our research method, data analysis and results. Thirdly, we present discussion, limitations and suggestions for future researches.

\section{Theoretical Background}

The use of technology is important due to improving efficiency and effectiveness and almost every sectors use technology (Liljander et al., 2006: 177; Partala \& Saari, 2015: 381; Stock \& Grob, 2016: 2166; Acar \& Gürol, 2018: 59; Cibaroğlu \& Turan, 2018: 204; Haidari et al., 2019: 229). People show avoidance, approach and neutral behavioral responses to new/ high technology-based product and service. Everett Rogers developed the diffusion theory of innovation. According to the theory, more relative advantage, compatibility, simplicity, trialability and observability innovations will be adopted faster than other innovations. Besides, diffusion of new ideas is affected by innovation itself, communication channel, time and social system. Moreover, adopting a new idea, there are five adopter categories in terms of members of the social system. These are i) innovators $(2.5 \%)$, ii) early adopters $(13.5 \%)$, iii) early majority (34\%), iv) late majority (34\%), v) laggards (\%16) (Rogers \& Scott, 1997).

People have two different views including favorable and unfavorable about technologybased products and services. TRI developed by Parasuraman (2000) contain the different views. Technology readiness is defined as "people's propensity to embrace and use technologies for accomplishing goals in home life and at work" (Parasuraman, 2000: 308). The definition of TRI's dimension is shown Table 1. TRI has used to determine individuals' willingness to use of technology. Optimism and Innovativeness is drivers of TRI while others are inhibitors of technology readiness. 
Table 1: Dimensions and Definition of TRI

\begin{tabular}{ll}
\hline Dimensions of TRI & Definition \\
\hline Optimism (OPT) & $\begin{array}{l}\text { A positive view of technology and a belief that it offers people } \\
\text { increased control, flexibility, and efficiency in their lives }\end{array}$ \\
\hline Innovativeness (INN) & A tendency to be a technology pioneer and thought leader \\
\hline Discomfort (DIS) & $\begin{array}{l}\text { A perceived lack of control over technology and feeling of being } \\
\text { overwhelmed by it }\end{array}$ \\
\hline Insecurity (INS) & $\begin{array}{l}\text { Distrust of technology and skepticism about its ability to work } \\
\text { properly. }\end{array}$ \\
\hline
\end{tabular}

TRI construct is important for marketers. Marketers can determine profile of potential adopters according to the construct and formulate positioning and communication strategies according to profiles of potential adopters (Lam et al., 2008: 20).

TR 2.0 was developed by Parasuraman \& Colby (2015). The construct is developed to be helpful in understanding the dynamics behind adoption of various technologies. Many researchers have conducted several studies on new or high technology. These are age (Venkatesh et al., 2003: 447), culture (Srite \& Karahanna, 2006: 679; Singh, 2006: 173; Elliot et al., 2008: 11), user experience (Partala \& Saari, 2015: 381), optimal technology adoption (Hagspiel et al., 2015: 897), rural and urban students for use of computer and internet, usage patterns of OPAC and the ease of OPAC use and their expectations from OPAC (Kumar, 2012: 144).

TRI has investigated in terms of different perspectives in current literature. These are demographic characteristics and others. TRI was investigated by demographic characteristics such as gender, age, income, education level (Demirci \& Ersoy, 2008: 6; Lee et al., 2010: 53). Other studies were conducted on cross-cultural validity of technology readiness index (Meng et al, 2009: 19), cosmopolitanism, global identification, promotion focus, prevention focus (Westjohn et al., 2009: 250), self-service technologies (SST) (Liljander et al., 2006: 177; see Ramaseshan et al., 2015 for dimensions of SST), actual/alternative collaboration technology use (Olschewski et al., 2013: 620), social technology readiness in term of knowledge workers (Stock \& Grob, 2016: 2166), usage patterns (Son \& Han, 2011: 1178), internet adoption time and use of the internet (Lam, et al., 2008: 19), different variables such as experience, industry trust, switching costs, satisfaction and service quality for $\mathrm{B}_{2} \mathrm{~B}$ (Vize et al. 2013: 909), moderating role of gender and technology readiness (Borrero et al., 2014: 39).

TAM construct was developed by Davis et al. (1989). The construct was comprised of two dimensions such as perceived usefulness (US) and perceived ease of use (EA). The dimensions impact adoption technology. Davis (1989: 320) defines US as "the degree to which a person believes that using a particular system would enhance his or her job performance" and EA as "the degree to which a person believes that using a particular system would be free of effort". TAM construct was used a lot of different studies (Cibaroğlu \& Turan, 2018: 204; Yildırır \& Kaplan, 2019: 22; Özer et al., 2019:65). While EA is only determined by external variables, US is also determined by EA. TAM construct is an adaptation of Fishbein and Ajzen's (1975) and Ajzen and Fishbein's (1980) theory of reasoned action. The use of technology of an 
individual impact by US and EA according to the construct. After, Venkatesh and Davis (2000) developed TAM2. TAM2 is built on TAM and added social influence and cognitive instrumental processes. Later, Venkatesh \& Bala (2008) developed TAM3. TAM3 as determinants of EA were added computer self-efficacy, perceptions of external control, computer anxiety, computer playfulness, perceived enjoyment and objective usability.

TRI and TAM constructs are combined into one model (TRAM) (Lin et al., 2007: 641). Researchers with TRAM construct integrate both system and individual aspects. A number of studies were conducted to test the relationship between TRI and TAM (Godoe \& Johansen, 2012: 38; Olschewski et al., 2013: 620). Olschewski et al. (2013) did not find a significant relationship among the variables while Godoe \& Johansen (2012: 38) found OPT and INN significantly influences perceived usefulness and perceived ease of use and perceived usefulness has a significant positive influence on actual usage. Tsourela ve Roumeliotis (2015: 124) examined the moderating role of technology readiness in acceptance and actual use of technology-based service and they found the effect.

$\mathbf{H}_{\mathbf{1}}$ : There is difference among different academic title of participation in terms of technology reading and technology acceptance; a) OPT b) INN c) DIS d) INS e)US f) EA

$\mathbf{H}_{2}$ : There is difference among different working unit of participation in terms of technology reading and technology acceptance; a) OPT b) INN c) DIS d) INS e) US f)EA

$\mathbf{H}_{3}$ : There is difference among different age of participation technology reading and technology acceptance; a) OPT b) INN c) DIS d) INS e) US f) EA

$\mathbf{H}_{4}$ : There is difference between female and male in terms of technology reading and technology acceptance; a) OPT b) INN c) DIS d) INS e) US f) EA

$\mathbf{H}_{5}$ : OPT has a positive effect on; a) US b) EA

$\mathbf{H}_{\mathbf{6}}$ : INN has a positive effect on; a) US b) EA

$\mathbf{H}_{7}$ : INS has a negative effect on; a) US b) EA

$\mathbf{H}_{\mathbf{8}}$ : DIS has a negative effect on; a) US b) EA

$\mathbf{H}_{9}$ : EA has a positive effect on US

\section{Research Method}

This study was carried out between the dates of March 2016 and June 2016. The data of the study have been collected by web-based survey method. The study population consists of academicians in different faculties, institutes and schools of Aksaray University, Middle East Technical University and Karadeniz Technical University. The study was used convenience sample method and 206 Turkish academicians were completed the survey.

The study was used two scales. These are TRI and TAM. TRI was adapted from Parasuraman (2000). TAM was adapted from Davis (1989). TRI has 36 items which it is optimism (10 items), innovativeness ( 7 items), discomfort (10 items), and insecurity (9 items) dimensions. TAM has 12 items which are perceived usefulness (6 items) and perceived ease of use (6 items). 


\section{Data Analysis and Results}

\subsection{General Statistics}

Table 2 shows the demographic features of participants. The 206 survey participants mostly were male $(65 \%)$, between 30 and 49 years old $(74 \%)$, doctorate education $(75 \%)$, married $(78 \%)$, assistant professor (32\%), faculty working unit (67\%), income between 4001 and 7000 TL (52\%).

\section{Table 2: Sample Characteristics}

\begin{tabular}{|c|c|c|c|}
\hline $\begin{array}{l}\text { Sample } \\
\text { Characteristic } \\
\end{array}$ & Items & Frequency & Percentage (\%) \\
\hline \multirow{2}{*}{ Gender } & Female & 72 & 35 \\
\hline & Male & 134 & 65 \\
\hline \multirow{5}{*}{ Age } & $29 /-$ & 40 & 19 \\
\hline & $30-39$ & 100 & 49 \\
\hline & $40-49$ & 52 & 25 \\
\hline & $50-59$ & 12 & 6 \\
\hline & $60 /+$ & 2 & 1 \\
\hline \multirow{3}{*}{ Education } & Undergraduate & 5 & 3 \\
\hline & Master & 46 & 22 \\
\hline & Doctorate & 155 & 75 \\
\hline \multirow{2}{*}{ Marital Status } & Single & 46 & 22 \\
\hline & Married & 160 & 78 \\
\hline \multirow{7}{*}{ Academic Title } & Specialist & 3 & 2 \\
\hline & Research Assistant & 39 & 19 \\
\hline & Research Assistant, Phd. & 2 & 1 \\
\hline & Instructor & 50 & 24 \\
\hline & Assistant Professor & 67 & 32 \\
\hline & Associate Professor & 27 & 13 \\
\hline & Professor & 18 & 9 \\
\hline \multirow{4}{*}{$\begin{array}{l}\text { Academics Unit of } \\
\text { Participation }\end{array}$} & Graduate School & 3 & 2 \\
\hline & Faculty & 139 & 67 \\
\hline & Schools & 12 & 6 \\
\hline & Vocational Schools & 52 & 25 \\
\hline \multirow{6}{*}{ Income } & 3000TL /- & 2 & 1 \\
\hline & $3001-4000 \mathrm{TL}$ & 36 & 17 \\
\hline & $4001-5000 \mathrm{TL}$ & 60 & 29 \\
\hline & $5001-6000 \mathrm{TL}$ & 24 & 12 \\
\hline & $6001-7000 \mathrm{TL}$ & 23 & 11 \\
\hline & $7001 \mathrm{TL}$ and over & 61 & 30 \\
\hline
\end{tabular}




\subsection{Primary Analysis}

Confirmatory factor analyses (CFA) were conducted to determine reliability and validity of TRI and TAM scales. Only 1 item (INN2) from INN construct was deleted (from examining low factor loading, modification index and residual matrix value) and then model fit was substantially improved. Model fit measures of measurement model suggested acceptable fit to data. For TRI, the coefficient of factor loading on the latent construct ranged from 0,33 to 0 , 85 and each indicator t-value exceeded 4,64 (recommended t-value 1,96). Convergent validity is evident in that all confirmatory factor loadings are significant ( $\mathrm{t}$ values range from 4, 64 to 15, 07). Similarly, for TAM, the coefficient of factor loading on the latent construct ranged from 0,66 to 0,96 and each indicator t-value exceeded 10,35 (recommended t-value 1,96). Convergent validity is evident in that all confirmatory factor loadings are significant ( $\mathrm{t}$ values range from 10,35 to 18,81$)$. Composite construct reliability $(\mathrm{CR})$ and Cronbach Alpha $(\alpha)$ of all the scales were greater than 0.60 (Bagozzi \& Yi, 1988; Hair et al., 1998). The results supported reliability of all of the scales.

\section{Table 3: Reliability of TRI Scale}

\begin{tabular}{|c|c|c|c|}
\hline Constructs & Stand. loading & CR & $\alpha$ \\
\hline$O P T$ & & .92 & .92 \\
\hline OPT1 & $.67(10.71)$ & & \\
\hline OPT2 & $.57 \quad(8.62)$ & & \\
\hline OPT3 & $.64(10.04)$ & & \\
\hline OPT4 & $.67(10.67)$ & & \\
\hline OPT5 & $.85(15.06)$ & & \\
\hline OPT6 & $.85(15.07)$ & & \\
\hline OPT7 & $.84(14.55)$ & & \\
\hline OPT8 & .68 (10.74) & & \\
\hline OPT9 & $.80(13.65)$ & & \\
\hline OPT10 & $.58 \quad(8.91)$ & & \\
\hline$I N N$ & & .85 & .85 \\
\hline INN1 & $.64 \quad(9.66)$ & & \\
\hline INN3 & $\begin{array}{ll}.51 & (7.39) \\
\end{array}$ & & \\
\hline INN4 & $.67(10.34)$ & & \\
\hline INN5 & $.83(13.81)$ & & \\
\hline INN6 & $.76(12.13)$ & & \\
\hline INN7 & $.71 \quad(11.04)$ & & \\
\hline$D I S$ & & .81 & .80 \\
\hline DIS1 & $.41 \quad(5.79)$ & & \\
\hline DIS2 & $.40 \quad(5.72)$ & & \\
\hline DIS3 & $.59 \quad(8.80)$ & & \\
\hline
\end{tabular}




\section{Table 3 continued}

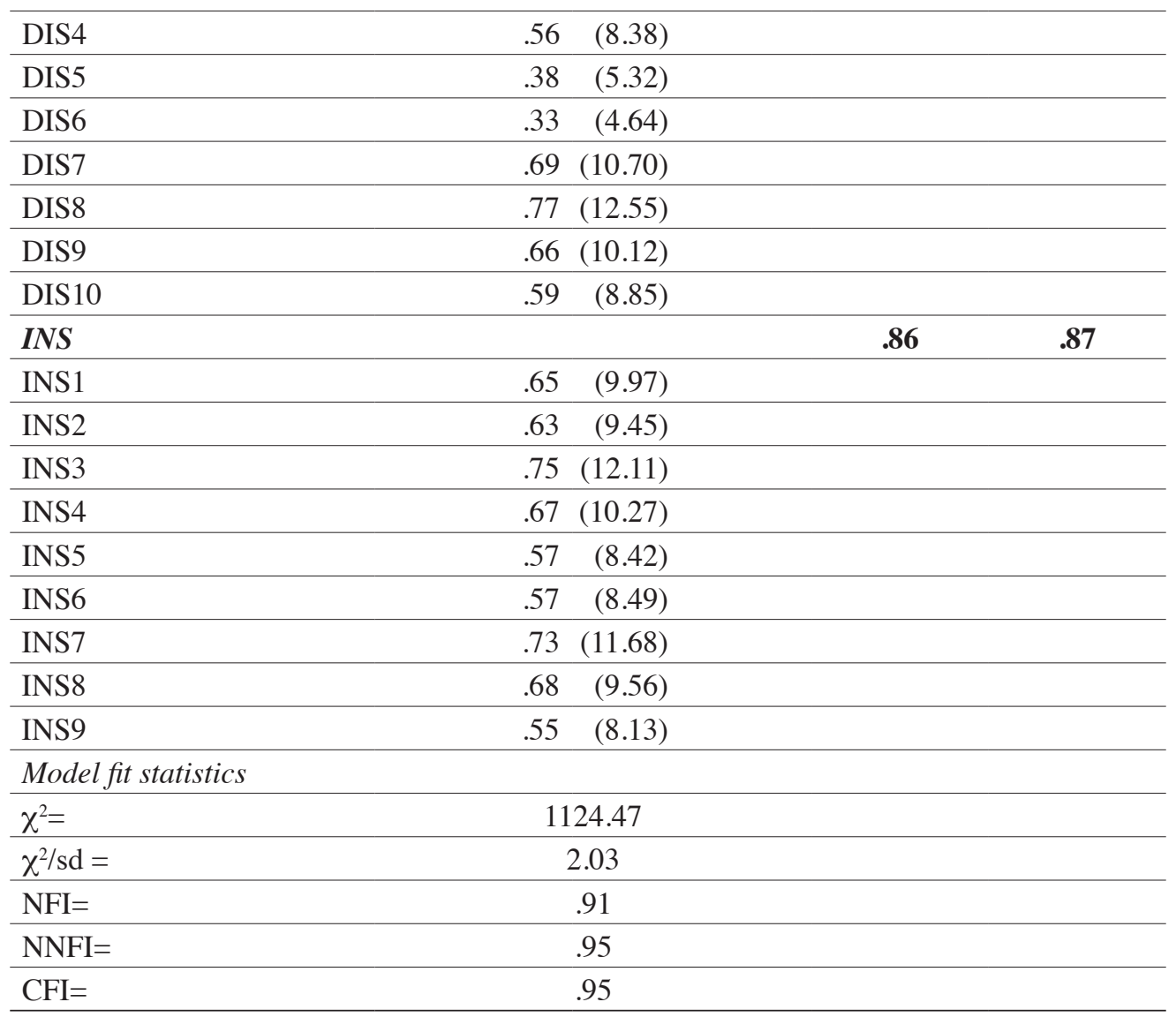

Discriminant validity of constructs was conducted with chi-square difference test. The $\chi^{2}$ values of the constrained and unconstrained models were compared and the $\chi^{2}$ differences were much larger than the 12,59 threshold, the result showed the existence of discriminant validity between the entire model constructs $\left(\Delta \chi^{2}=1727,92, \Delta \mathrm{sd}=6, \mathrm{p}=0.05\right)$.

The $\chi^{2}$ values of the constrained and unconstrained models were compared and the $\chi^{2}$ differences were much larger than the 3,8446 threshold, the result showed the existence of discriminant validity between the entire model constructs $\left(\Delta \chi^{2}=210.51, \Delta \mathrm{sd}=1, \mathrm{p}=0.05\right)$. The results supported validity and reliability of all of the subscales. 
Hülya BAKIRTAŞ, Cemil AKKAŞ

Table 4: Discriminant Validity of TRI Scale

\begin{tabular}{lcc}
\hline Models & $\chi^{2}$ & sd \\
\hline Constraint model & 2852.39 & 559 \\
\hline Unconstrained model & 1124.47 & 553 \\
\hline$\Delta \chi^{2}$ & 1727.92 & 6 \\
\hline$\Delta$ sd & & \\
\hline \multicolumn{3}{c}{$6 \chi^{2} .05=12.5916$} \\
\hline
\end{tabular}

Table 5: Reliability of TAM Scale

\begin{tabular}{lccc}
\hline Constructs & Stand.loading & CR & $\boldsymbol{\alpha}$ \\
\hline $\boldsymbol{U} \boldsymbol{S}$ & & $\mathbf{9 7}$ & $\mathbf{9 7}$ \\
\hline US1 & $.82(14.21)$ & & \\
\hline US2 & $.94(17.97)$ & \\
\hline US3 & $.96(18.81)$ & \\
\hline US4 & $.96(18.71)$ & \\
\hline US5 & $.94(17.83)$ & .91 \\
\hline US6 & $.88(16.16)$ & \\
\hline EA & & \\
\hline EA1 & $.89(16.05)$ & \\
\hline EA2 & $.66(10.35)$ & \\
\hline EA3 & $.78(13.12)$ & \\
\hline EA4 & $.84(14.50)$ & \\
\hline EA5 & $.84(14.53)$ & \\
\hline EA6 & $.75(12.22)$ & \\
\hline Model fit statistics & & \\
\hline$\chi^{2}=$ & 309.78 & \\
\hline$\chi^{2} /$ sd $=$ & 5.95 & \\
\hline NFI= & .95 & \\
\hline NNFI= & .95 & \\
\hline CFI= & .96 & \\
\hline
\end{tabular}

Table 6: Discriminant Validity of TAM Scale

\begin{tabular}{lcc}
\hline Models & $\chi^{2}$ & sd \\
\hline Constraint model & 520.29 & 53 \\
\hline Unconstrained model & 309.78 & 52 \\
\hline$\Delta \chi^{2}$ & 210.51 & \\
\hline$\Delta$ sd & & 1 \\
\hline $1 \chi^{2} .05=3,8446$ & & \\
\hline
\end{tabular}




\subsection{Hypotheses Testing}

One-way analysis of variance (ANOVA) was conducted to determine differences of subscales of technology reading index and technology acceptance model according to academic title of participation. The INS subscales of technology reading index were statistically different according to academic title of participation. The results of the ANOVA analysis showed significant differences between Group 4 and Group 2. The ANOVA results, Table 7, support the $\mathrm{H}_{1 \mathrm{~d}}$ hypothesis. $\mathrm{H}_{\text {la,b,c,e, } \mathrm{f}}$ are not supported. ANOVA was conducted to determine differences of factors of technological readiness and technology acceptance model according to working unit of participation. The factors of technological readiness and technology acceptance model were not statistically different according to working unit of participation. The ANOVA results, Table 7 , not support the hypothesis.

Table 7: Comparison of Subscales of Technology Reading and TAM by Academic Title of Participation and Working Unit of Participation

\begin{tabular}{lccccccc}
\hline Factors & $\begin{array}{c}\text { Group 1 } \\
\text { Prof. } \\
\text { Mean/SD }\end{array}$ & $\begin{array}{c}\text { Group 2 } \\
\text { Assoc. } \\
\text { Prof. } \\
\text { Mean/SD }\end{array}$ & $\begin{array}{c}\text { Group 3 } \\
\text { Assist. } \\
\text { Prof. } \\
\text { Mean/SD }\end{array}$ & $\begin{array}{c}\text { Group 4 } \\
\text { Others } \\
\text { Mean/SD }\end{array}$ & $F$-value & $p$-value & Differ \\
\hline Academic title of participation & & & & & \\
\hline OPT & $3.68(1.14)$ & $3.84(0.93)$ & $4.02(0.78)$ & $4.12(0.74)$ & 1.876 & 0.135 & - \\
\hline INN & $3.21(0.90)$ & $3.34(0.82)$ & $3.23(0.77)$ & $3.47(0.98)$ & 1.162 & 0.325 & - \\
\hline DIS & $3.54(0.73)$ & $3.46(0.68)$ & $3.54(0.69)$ & $3.64(0.64)$ & 0.700 & 0.553 & - \\
\hline & & & & & & & Group \\
INS & $3.26(0.90)$ & $3.01(0.90)$ & $3.40(0.83)$ & $3.50(0.83)$ & 2.401 & 0.069 & $\begin{array}{c}\text { and } \\
\text { Group 2 }\end{array}$ \\
\hline US & $3.90(1.38)$ & $4.18(1.09)$ & $4.45(0.97)$ & $4.45(0.87)$ & 2.018 & 0.113 & - \\
\hline EA & $3.65(1.03)$ & $3.82(1.08)$ & $4.07(0.77)$ & $4.11(0.82)$ & 1.999 & 0.115 & - \\
\hline
\end{tabular}

Working unit of participation

\begin{tabular}{llllllll}
\hline OPT & $3.97(0.84)$ & $4.17(0.67)$ & $4.48(0.38)$ & $4.01(0.83)$ & 1.472 & 0.223 & - \\
\hline INN & $3.32(0.87)$ & $3.28(1.01)$ & $3.38(0.99)$ & $3.47(0.90)$ & 0.400 & 0.753 & - \\
\hline DIS & $3.57(0.65)$ & $3.80(0.26)$ & $3.75(0.63)$ & $3.57(0.73)$ & 0.369 & 0.776 & - \\
\hline INS & $3.32(0.88)$ & $3.93(0.65)$ & $3.67(0.75)$ & $3.47(0.80)$ & 1.291 & 0.279 & - \\
\hline US & $4.35(1.03)$ & $4.50(0.50)$ & $4.72(0.45)$ & $4.33(0.99)$ & 0.568 & 0.636 & - \\
\hline EA & $4.00(0.90)$ & $4.11(0.86)$ & $4.24(0.74)$ & $4.04(0.84)$ & 0.273 & 0.845 & -
\end{tabular}

* Although Specialist (3), Research Assistant (39), Research Assistant, Phd. (2) and Instructor (50) are reported in Table 1 , they were combined under the title of Others

ANOVA was conducted to determine differences of factors of technological readiness and technology acceptance model according to age of participation. The results are reported in Table 8. The factors of technological readiness and technology acceptance model were not statistically different according to age of participation. The ANOVA results, Table 8, not support the hypothesis. 
Table 8: Comparison of Subscales of Technology Reading and TAM by Age

\begin{tabular}{lcccccc}
\hline Factors & $\begin{array}{c}\text { 29 and } \\
\text { under age } \\
\text { Mean/SD }\end{array}$ & $\begin{array}{l}\text { 30-39 age } \\
\text { Mean/SD }\end{array}$ & $\begin{array}{l}\text { 40-49 age } \\
\text { Mean/SD }\end{array}$ & $\begin{array}{c}\text { 50 and } \\
\text { over age* } \\
\text { Mean/SD }\end{array}$ & F-value & $\boldsymbol{p}$-value \\
\hline OPT & $4.19(0.63)$ & $3.99(0.85)$ & $3.97(0.81)$ & $3.72(1.10)$ & 1.277 & 0.284 \\
\hline INN & $3.49(0.95)$ & $3.41(0.86)$ & $3.23(0.88)$ & $3.07(0.84)$ & 1.309 & 0.273 \\
\hline DIS & $3.67(0.61)$ & $3.55(0.66)$ & $3.65(0.66)$ & $3.33(0.89)$ & 1.171 & 0.322 \\
\hline INS & $3.50(0.79)$ & $3.42(0.86)$ & $3.25(0.90)$ & $3.28(0.81)$ & 0.834 & 0.476 \\
\hline US & $4.59(0.72)$ & $4.40(0.96)$ & $4.20(1.08)$ & $4.07(1.38)$ & 1.634 & 0.183 \\
\hline EA & $4.24(0.75)$ & $4.08(0.85)$ & $3.88(0.90)$ & $3.59(1.35)$ & 2.628 & 0.051 \\
\hline
\end{tabular}

* Although participants between the ages of 50-59 and 60+ are reported in Table 1, they were combined with those aged 50 and over for these analyzes.

An independent samples t-test was conducted to explore both the technology reading index (OPT, INN, DIS and INS) and TAM (US and EA) by comparing the means of males and females. As seen Table 10 , there was no significant difference in the scores between two groups for OPT, $\mathrm{t}(204)=0,432, \mathrm{p}>0,05$, two-tailed with male scoring slightly higher than female scoring; for DIS, $\mathrm{t}(204)=0,311, \mathrm{p}>0,05$, two-tailed with male scoring slightly higher than female scoring; for INS, $t(204)=-1,61, p>0,05$, two-tailed with female scoring higher than male scoring. There was a significant difference in the scores between two groups for INN, $t$ (204) $=2,911, \mathrm{p}<0,05$, two-tailed with male scoring slightly higher than female scoring. The magnitude of the differences in the means (mean difference $=0,37,95 \% \mathrm{CI}: 0,12$ to 0,62 ) was small (eta squared $=0,01$ ). There was a difference between these groups in terms of INN.

Table 9: T-Test Comparing Technology Reading Index and TAM With Sex

\begin{tabular}{lccccc}
\hline Variable & $\mathbf{N}$ & Mean & SD & t-value & $p$-value \\
\hline OPT & & & & & \\
Male & 134 & 4.03 & 0.81 & 0.432 & 0.66 \\
Female & 72 & 3.97 & 0.84 & & \\
\hline$I N N$ & & & & & $0.00^{*}$ \\
Male & 134 & 3.49 & 0.90 & 2.911 & \\
Female & 72 & 3.12 & 0.81 & & 0.75 \\
\hline$D I S$ & & & & & \\
Male & 134 & 3.59 & 0.66 & 0.311 & 0.11 \\
Female & 72 & 3.57 & 0.69 & & \\
\hline$I N S$ & & & & & \\
Male & 134 & 3.32 & 0.84 & -1.610 & \\
Female & 72 & 3.52 & 0.87 & & \\
\hline$U S$ & & & & & \\
Male & 134 & 4.43 & 0.95 & 1.135 & \\
Female & 72 & 4.26 & 1.06 & & \\
\hline EA & & & & & \\
Male & 134 & 4.06 & 0.82 & 0.687 & \\
Female & 72 & 3.97 & 0.96 & & \\
\hline
\end{tabular}


As seen Table 9, there was no significant difference in the scores between two groups for US, $\mathrm{t}(204)=1,135, \mathrm{p}>0,05$, two-tailed with male scoring slightly higher than female scoring; for EA, $\mathrm{t}(204)=0,687, \mathrm{p}>0,05$, two-tailed with male scoring slightly higher than female scoring.

Structural equation modeling (SEM) was used to analyze the hypothesis. The measurement model was constructed to estimate the relationships between the constructs and their indicators before the structural models were tested. Measurement model was estimated and Table 10 contains the fit statistics and scale reliabilities. As shown in Table 10, model fit measures of measurement model suggested acceptable fit to data. The coefficient of factor loading on the latent construct ranged from .33 to .96 and each indicator t-value exceeded 4.62 (recommended t-value 1.96). The results supported convergent validity. Composite construct reliability $(\mathrm{CR})$ of all the scales was greater than 0.60 (Bagozzi \& Yi, 1988) and Cronbach a for each construct exceeded the recommended critical point of 0.60 . The results supported reliability of all of the scales.

Table 10: Measurement Model

\begin{tabular}{|c|c|c|c|}
\hline Constructs & Stand. loading & CR & $\alpha$ \\
\hline$O P T$ & & .92 & .92 \\
\hline OPT1 & $.70(11.22)$ & & \\
\hline OPT2 & $.56(8.60)$ & & \\
\hline OPT3 & $.65(10.30)$ & & \\
\hline OPT4 & $.68(10.90)$ & & \\
\hline OPT5 & $.86(15.24)$ & & \\
\hline OPT6 & $.86(15.15)$ & & \\
\hline OPT7 & $.82(14.13)$ & & \\
\hline OPT8 & $.68(10.88)$ & & \\
\hline OPT9 & $.79(13.46)$ & & \\
\hline OPT10 & $.58(8.90)$ & & \\
\hline INN & & 84 & .85 \\
\hline INN1 & $.62(9.66)$ & & \\
\hline INN3 & $.49(7.06)$ & & \\
\hline INN4 & $.68(10.45)$ & & \\
\hline INN5 & $.83(13.80)$ & & \\
\hline INN6 & $.76(12.22)$ & & \\
\hline INN7 & $.73(11.51)$ & & \\
\hline$D I S$ & & .81 & .80 \\
\hline DIS1 & $.41(5.77)$ & & \\
\hline DIS2 & $.40(5.73)$ & & \\
\hline DIS3 & $.59(8.80)$ & & \\
\hline DIS4 & $.56(8.35)$ & & \\
\hline DIS5 & $.38(5.31)$ & & \\
\hline DIS6 & $.33(4.62)$ & & \\
\hline
\end{tabular}




\section{Table 10 continued}

\begin{tabular}{llll}
\hline DIS7 & $.69(10.72)$ & \\
\hline DIS8 & $.77(12.57)$ & .86 & .87 \\
\hline DIS9 & $.66(10.12)$ & & \\
\hline DIS10 & $.59(8.85)$ & & \\
\hline INS & & \\
\hline INS1 & $.65(9.94)$ & \\
\hline INS2 & $.62(9.41)$ & \\
\hline INS3 & $.75(12.01)$ & \\
\hline INS4 & $.67(10.24)$ & \\
\hline INS5 & $.57(8.39)$ & \\
\hline INS6 & $.57(8.52)$ & \\
\hline INS7 & $.74(11.74)$ & \\
\hline INS8 & $.64(9.66)$ & \\
\hline INS9 & $.55(8.16)$ & \\
\hline US & & \\
\hline US1 & $.82(14.42)$ & \\
\hline US2 & $.94(17.92)$ & \\
\hline US3 & $.96(18.71)$ & \\
\hline US4 & $.96(18.67)$ & \\
\hline US5 & $.94(17.96)$ & \\
\hline US6 & $.88(16.16)$ & \\
\hline EA & & \\
\hline EA1 & $.87(15.64)$ & \\
\hline EA2 & $.64(10.09)$ & \\
\hline EA3 & $.79(13.25)$ & \\
\hline EA4 & $.85(15.02)$ & \\
\hline EA5 & $.84(14.79)$ & \\
\hline EA6 & $.74(12.08)$ & \\
\hline Model fit statistics & & \\
\hline $\boldsymbol{X}=$ & 2244.09 & \\
\hline$\chi$ 2/sd & 2.21 & \\
\hline RMSEA & 0.07 & \\
\hline NFI= & .93 & \\
\hline NNFI & & \\
\hline CFI= & & \\
\hline & & \\
\hline
\end{tabular}

Discriminant validity of constructs was conducted with chi-square difference test. The results are shown in Table 11. The $\chi^{2}$ values of the constrained and unconstrained models were compared and the $\chi^{2}$ differences were much larger than the 24,9958 threshold, the result showed the existence of discriminant validity between all the model constructs $\left(\Delta \chi^{2}=2940,83\right.$, $\Delta \mathrm{sd}=15, \mathrm{p}=0.05)$. 
Table 11: Discriminant Validity

\begin{tabular}{lcc}
\hline Models & $\chi^{2}$ & sd \\
\hline Constraint model & 5184.92 & 1032 \\
\hline Unconstrained model & 2244.09 & 1017 \\
\hline$\Delta \chi^{2}$ & 2940.83 & 15 \\
\hline$\Delta$ sd & \multicolumn{2}{c}{$15 \chi^{2} .05=24.9958$} \\
\hline
\end{tabular}

Table 12 was showed results of structural equation model. The results indicated an acceptable fit $\left(\chi^{2}=2244.08 ; \chi^{2} / \mathrm{df}=2.21 ; \mathrm{RMSEA}=.07\right.$; NFI $\left.=.93 ; \mathrm{NNFI}=.96 ; \mathrm{CFI}=.96\right)$. Thus, the findings provide a good basis for testing hypothesis. Hypothesis $\mathrm{H}_{7 \mathrm{a}}, \mathrm{H}_{7 \mathrm{~b}}, \mathrm{H}_{8 \mathrm{~b}}$ and $\mathrm{H}_{11}$ were supported, but others were rejected.

\section{Table 12: The Results of Structural Model}

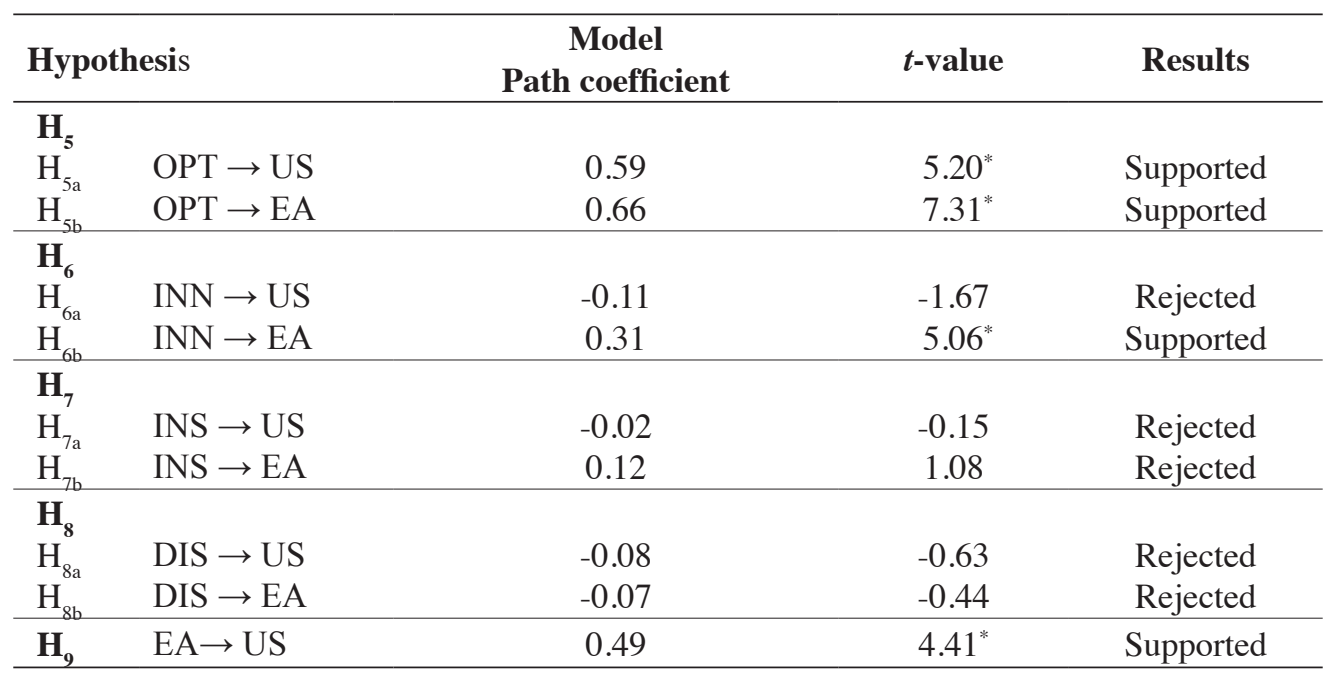

\section{Discussion}

The contribution of this extends to literature on technological readiness and technology acceptance in two important ways. First, the study focuses on technology with holistic perspectives. Second, the new technology subject examined in terms of Turkey sample and academic staff. The study investigates relationship among factors of technological readiness, technology acceptance, working unit and title of academic staff.

In the study, the authors found a significant difference in INS factor of technological readiness while they did not find significant difference technology acceptance for title of academic staff. The difference was between Group 4 (others) and Group 2 (Associate professor). For others, there is distrust about technology. Besides, the study was found that 
factors of both technology readiness and technology acceptance were not statistically different according to working unit and age of academic staff. Besides, the authors found a significant difference in INN factor of technological readiness for age of academic staff. Male was more innovativeness according to female about new technologies. Our findings reveal that optimism (OPT) personality dimensions of TRI influence both perceived usefulness and perceived ease of use. The finding can be interpreted such as; an individual who is optimistic in relation to technology can find a system more useful and easier than less optimistic an individual. Besides, the study found innovativeness (INN) personality dimensions of TRI influence perceived ease of use. The finding implies that an innovative individual can find a system easier of use than less innovative an individual. The finding is parallel current literature (Godoe \& Johansen, 2012: 38).

The implications of the study are important for education and training. The new generation has grown up in a technology environment. Expectations, attitudes and learning styles of the generation students have varied with the environment. Teachers should meet student's expectations and use appropriate learning styles for students. In this point of view, both managers and teachers should focus on their attention as regards technology and everybody should acquire basic technological ability. The other implications of the study are important technological product retailers and e-retailers: personality dimensions influence use of new technology. Retailers should develop strategies on how to stimulate use of new technological products according to target customers' personalities. Moreover, they should employ on how to reduce the insecurity perception of customers. At the same time, the marketing managers should pay attention to positioning and promoting based on customers' personalities.

The research has limitations. First, the study was conducted on academic staff. Future research should focus on different demographic characteristics (such as age, education level, income, occupation). Second, the survey was conducted in Turkey. Thus, the results cannot be applied directly to different countries. Future researchers should compare the result of the study. Future studies should consider the perspectives of others including developing/ developed countries, specific technological products, different universities, usage patterns, customer satisfaction and retention. (5)Technology readiness and technology acceptance of academicians can be researched with newly developed theories and measurement tools and its results compared with existing researches. In addition, the technology readiness and acceptance of academicians can be explored in robot technologies and distance education technologies, which is a more specific field.

\section{References}

Acar, Z., \& Gürol, P. (2018). Çalışanların teknoloji kullanım adaptasyonunun firmaların lojistik servis performansına etkisi. Doğuş Üniversitesi Dergisi, 19(1), 59-68.

Ajzen, I., \& Fishbein, M. (1980). Understanding attitudes and predicting social behavior. Englewood Cliffs, NJ: Prentice Hall.

Bagozzi, R. P., \& Yi, Y. (1988). On the evaluation of structural equation models. Journal of Academy of Marketing Science, 16, 74-94.

Borrero, J. D., Yousafzai, S. Y., Javed, U., \& Page, K. L. (2014). Expressive participation in internet social movements: Testing the moderating effect of technology readiness and sex on student sns use. Computers in Human Behavior, 30, 39-49. 
Brahima, S. (2017). The world in 2017: ICT facts and figures, https://www.itu.int/en/ITU-D/Statistics/ Pages/facts/default.aspx.

Cibaroğlu, M. O., \& Turan, A. H. (2018). Elektronik belge yönetim sistemlerinin genişletilmiş teknoloji kabul modeli temelinde kullanımı: Ampirik bir değerlendirme. Adnan Menderes Üniversitesi Sosyal Bilimler Enstitüsü Dergisi, 5(2), 204-217.

Davis, F. D. (1989). Perceived usefulness, perceived ease of use, and user acceptance of information technology. MIS Quarterly, 13(3), 319-340.

Demirci, A.E., \& Ersoy, N. F. (2008). Technology readiness for innovative high-tech products: How consumers perceive and adopt new technologies. Business Review, 10(2).

Elliott, K. M., Hall, M. C. \& Meng, J. G. (2008). Student technology readiness and its impact on cultural competency. College Teaching Methods \& Styles Journal (CTMS), 4(6), 11-22.

Fishbein, M., \& Ajzen, I. (1975). Belief, attitude, intention and behavior: An introduction to theory and research. Reading, MA: Addison-Wesley.

Godoe, P., \& Johansen, T. S. (2012). Understanding adoption of new technologies: Technology readiness and technology acceptance as an integrated concept. Journal of European Psychology Students, 3, 38-53.

Hagspiel, V., Huisman, K. J., \& Nunes, C. (2015). Optimal technology adoption when the arrival rate of new technologies changes. European Journal of Operational Research, 243, 897-911.

Haidari, S. M., Yelken, T. Y., \& Akay, C. (2019). Technology-enhanced self-directed language learning behaviors of efl student teachers. Contemporary Educational Technology, 10(3), 229-245.

Hair, J. E., Anderson, R. E., Tatman, R. L., \& Black, W. C. (1998). Multivariate data analysis. 5th Edition, New Jersey: Prentice-Hall.

Lam, S. Y., Chiang J., \& Parasuraman, A. (2008). The effects of the dimensions of technology readiness on technology acceptance: An empirical analysis. Journal of Interactive Marketing, 22(4),19-39.

Lee, H.-J., Cho, H.J., Xu, W., \& Fairhust, A. (2010). The influence of consumer traits and demographics on intentions to use retail self-service checkouts. Marketing Intelligence \& Planning, 28(1), 4658.

Liljander, V., Gillberg, F., Gummerus, J., \& Riel, A. van (2006). Technology readiness and the evaluation and adoption of self-service technologies. Journal of Retailing and Consumer Services, 13, 177191.

Lin, C., Shih H., \& Sher, P. J. (2007). Integrating technology readiness into technology acceptance: The tram model. Psychology and Marketing, 24(7), 641-657.

Kumar, S. (2012). Use of computer, internet, and library opacs among rural and urban postgraduates in Indian universities. OCLC Systems \& Services: International Digital Library Perspectives, 28(3), 144-163.

Meng, J. G., Elliot, K. M., \& Hall, M. C. (2009). Technology readiness index (TRI): Assessing crosscultural validity. Journal of International Consumer Marketing, 22, 19-31.

Olschewski, M., Renken, U. B., Bullinger, A. C., \& Möslein, K. M. (2013). Are you ready to use? Assesing the meaning of social influence and technology readiness in collaboration technology adoption. 46th Hawai International Conference on System Sciences, 620-629.

Özer, G., Günlük, M., \& Özcan, M. (2019). Muhasebe akademisyenlerinin muhasebe eğitiminde uzaktan eğitim uygulamaları kullanımına yönelik algılarının teknoloji kabul modeli çerçevesinde incelenmesi. Muhasebe ve Vergi Uygulamaları Dergisi, 12(1), 65-90.

Parasuraman, A. (2000). Technology readiness index (TRI): A multiple-item scale to measure readiness to embrace new technologies. Journal of Service Research, 2(4), 307-320. 
Parasuraman, A., \& Colby, C. L. (2015). An updated and streamlined technology readiness index: TRI 2.0. Journal of Service Research, 18(1), 59-74.

Partala, T., \& Saari, T. (2015). Understanding the most influential user experiences in succesful and unsuccesful technology adoptions. Computers in Human Behavior, 53, 381-395.

Ramaseshan, B., Kingshott, R. P. J., \& Stein, A. (2015). Firm self-service technology readiness. Journal of Service Marketing, 26(5), 751-776.

Rogers, E. M., \& Scott, K. L. (1997). The diffusion of innovations model and outreach from the national network of libraries of medicine to native American communities. https://nnlm.gov/archive/pnr/ eval/rogers.html.

Singh, S. (2006). Cultural differences in, and influences on consumers' propensity to adopt innovations. International Marketing Review, 23(2), 173-191.

Son, M., \& Han, K. (2011). Beyond the technology adoption: Technology readiness effects on postadoption behavior. Journal of Business Research, 64, 1178-1182.

Stock, R., \& Grob, M. (2016). How does knowledge workers' social technology readiness affect their innovative work behavior? 49th Hawaii International Conference on System Sciences, 2166-2175.

Srite, M., \& Karahanna, E. (2006). The role of espoused national cultural values in technology acceptance. MIS Quarterly, 30(3), 679-704.

Tsourela, M., \& Roumeliotis, M. (2015). The moderating role of technology readiness, gender, and sex in consumer acceptance and actual use of technology-based services. Journal of High Technology Management Research, 26, 124-136.

Westjohn, S. A., Arnold, M. J., Magnusson, P., Zdravkovic, S., \& Zhou, J. X. (2009). Technology readiness and usage: A global-identity perspective. Journal of the Academy Marketing Science, 37, 250-265.

Venkatesh, V., \& Davis, F. D. (2000). A theoretical extension of the technology acceptance model: Four longitudinal field studies. Management Science, 46(2), 186-204.

Venkatesh, V., Morris, M. G., Davis, G. B., \& Davis, F. D. (2003). User acceptance of information technology: Towards a unified view. MIS Quarterly, 27(3), 425-478.

Venkatesh, V., \& Bala, H. (2008). Technology acceptance model 3 and a research agenda on interventions. Decisions Sciences, 39(2), 273-315.

Vize, R., Coughlan, J., Kennedy, A., \& Ellis-Chadwick, F. (2013). Technology readiness in a B2B online retail context: An examination of antecedents and outcomes. Industrial Marketing Management, 42, 909-918.

Yıldırır, S. C., \& Kaplan, B. (2019). Mobil uygulama kullanımının benimsenmesi: Teknoloji kabul modeli ile bir çalışma. Kafkas Üniversitesi İktisadi ve İdari Bilimler Fakültesi Dergisi, 10(19), 22-51. 